\title{
Vocational Training and Education in the Library and Information Professions in Switzerland: An Overview and Some Reflections
}

\author{
Regula Feitknecht, ${ }^{1}$ Jasmine Lovey ${ }^{2}$
}

\section{Preface: the vocational training system in Switzerland}

In Switzerland, vocational and basic professional training is based on an integrated apprenticeship system. This system provides a degree called the Federal Diploma of Vocational Education and Training (VET) in some 650 different occupations ${ }^{3}$. It can be applied for after compulsory schooling; the VET is awarded after successfully completing three years (or four years in some cases) of on-the-job training.

The legal basis of this system is the Vocational and Professional Education and Training Act ${ }^{4}$ and its accompanying ordinance ${ }^{5}$. The stated objective of this training system is to help people obtain the knowledge and skills needed to practice a profession and to prepare them for lifelong learning, be it within an institution of learning or through self-training.

\section{Professional training in the field of library and information science}

While the nationally organized system of apprenticeships already came into being in the late $19^{\text {th }}$ century ${ }^{6}$, the library trades were only integrated

\footnotetext{
${ }^{1}$ Cantonal and University Library, Fribourg, Switzerland.

2 University of Fribourg, Switzerland.

3 "CFC", Orientation.ch, accessed on 22.01.2020, www.orientation.ch.

${ }^{4}$ Admin.ch, accessed on 22.01.2020, www.admin.ch/opc/fr/classified-compilation/200 01860/index.html.

5 Admin.ch, accessed on 22.01.2020, www.admin.ch/opc/fr/classified-compilation/ 20031709/index.html.

6 Philipp Gonon, «Apprentissage», Dictionnaire historique de la Suisse, November 11, 2007 https://hls-dhs-dss.ch/fr/articles/027827/2007-11-29/, accessed on 22.01.2020.
} 
into this system at a late stage. The umbrella association of Swiss librarians, BBS 7 , continued to offer a three-year course of on-the-job training for trainees with a secondary school degree until 1998.

It was only in 1998 that the Swiss library world witnessed the first generation of apprentices launch their careers; they would go on to graduate as VET Information and Documentation Agents in 2001.

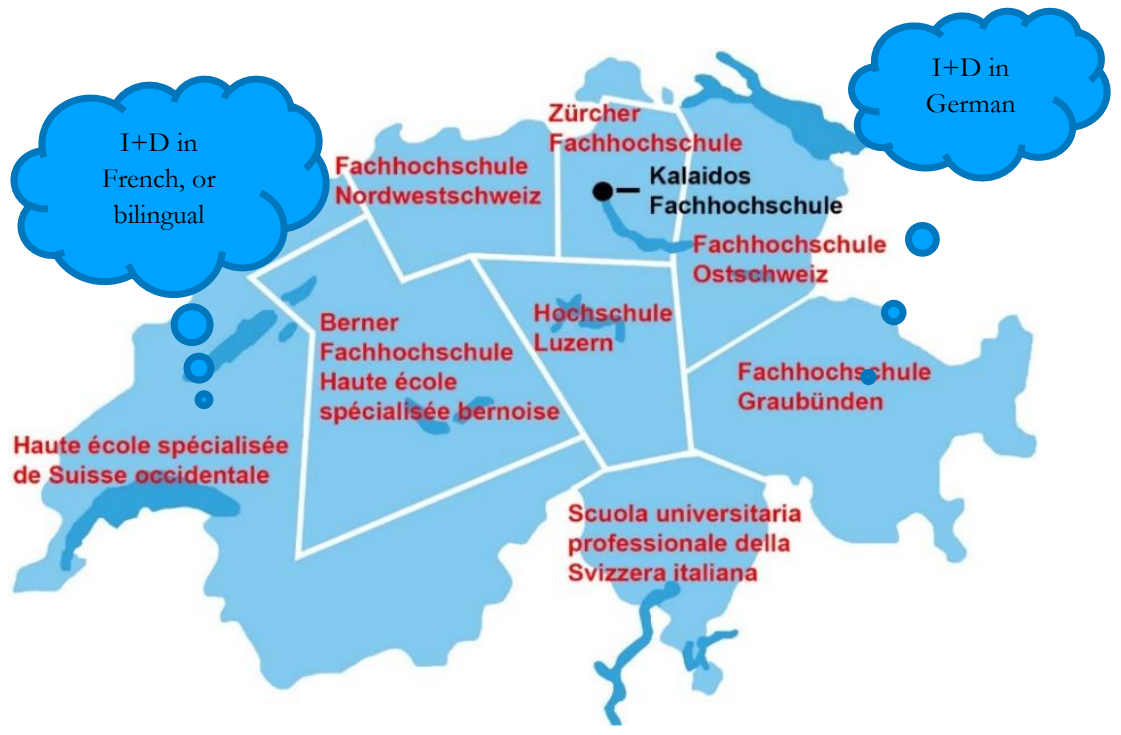

The path to a bachelor or master's degree from an HEG does not necessarily pass through an apprenticeship. Holders of a secondary education degree can also access it through a one-year "professional immersion" course that sees them work in a library or archive. University graduates can also apply for these degrees.

With career paths now ranging from an apprenticeship to a consecutive master's degree ${ }^{8}$, formal education in the field has greatly

\footnotetext{
${ }^{7} \mathrm{BBS}$, or Association des bibliothèques et bibliothécaires suisses; since 2019, Bibliosuisse. https://bibliosuisse.ch/, accessed on 27.01.2020.

8 "Bibliothèque information suisse BIS", arbido.ch, https://arbido.ch/fr/editionarticle/2015-1/associations-i-d/biblioth $\%$ C3\%A8que-information-suisse-bis, accessed on 20.01.2020.
} 
evolved. Schematically, the possible training paths can be represented in the following way:

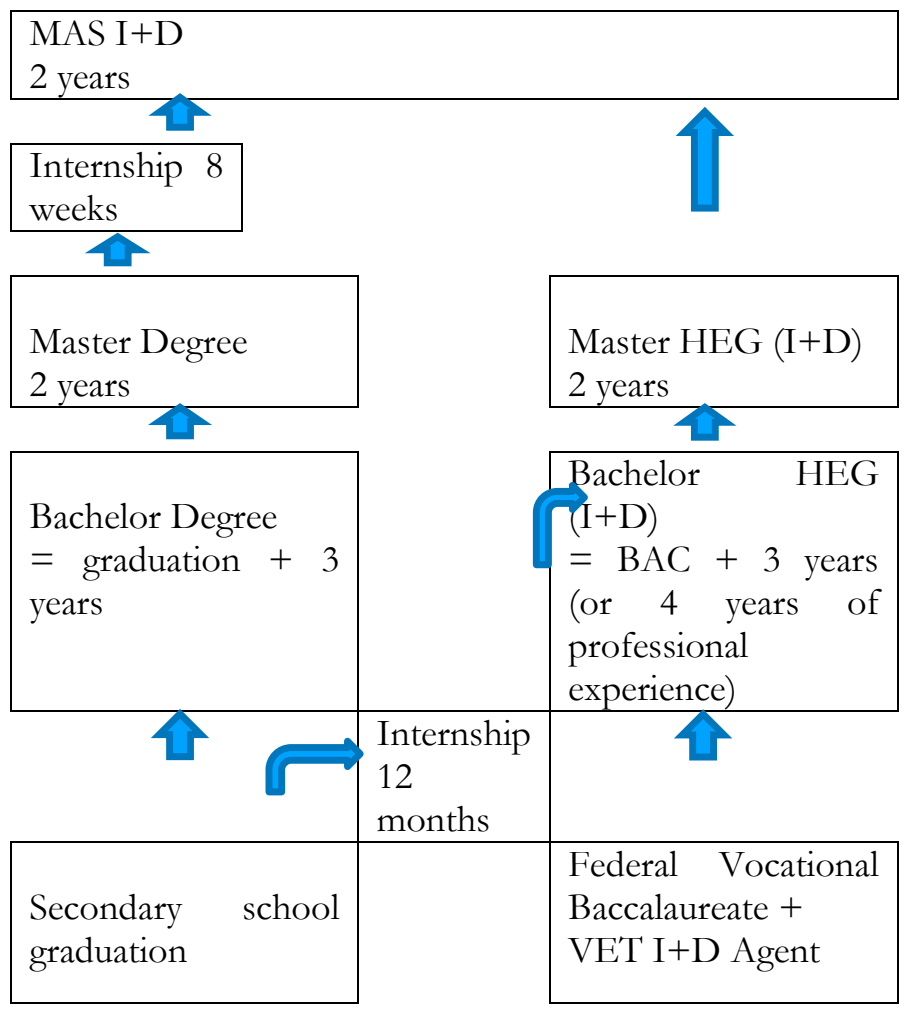

This variety of paths to vocational and university training for jobs in the field of LIS allows young people to work at different institutions or private companies and in different functions, all according to their respective skill profiles.

\section{Technical fact sheet of the main diplomas}

In the followings, a brief presentation of the three main levels of professional training will help to understand their intricacies. 


\section{A. Apprenticeship (VET Information and Documentation Agent)}

- Admission requirements: compulsory schooling successfully completed; be hired as an apprentice by a training institution (libraries, archives, etc.)

- Total duration: 3 years.

- Practical training in an information/documentation service (3-4 days a week).

- Theoretical training at vocational school (1-2 days per week). Classes are taught by trainers who specialize in various areas of library management. The following branches are taught: "Acquisition and reception," "Cataloguing, inventory and classification," "Retention and preservation," "Information and reproduction technology," "Internal and external communication," "Research and reference," "Information and culture," "Administration," "General Culture," "Sport."

- Inter-company courses (a total of 29 days over 3 years). The aim is to bring together in block courses (which usually last a week or more) apprentices from different institutions, in order to encourage the exchange of professional practices and mutual knowledge.

- Job prospects: Information and Documentation Agents find jobs in public or private documentation centres, libraries, archives, museums, publishing houses, news agencies, etc. They can take charge of a unit or a department as long as their experience, the ongoing training they undergo and their foreign language proficiency give them the necessary skills.

- Evolution: every five years, the curriculum undergoes a review in order to offer up-to-date training. Currently, a survey is underway to design the curriculum for the years 2022 and beyond.

\section{B. Bachelor (Documentary Information Specialist)}

- Admission requirements: VET Information and Documentation Agent and Federal Vocational Baccalaureate, or secondary school graduation and a one-year professional immersion internship in a training institution. 
- Total duration: 3 years of full-time or 4 years of part-time study (the duration of studies is subject to the rules of the Bologna system) ${ }^{9}$.

- Theoretical training: at one of the two specialized universities of applied sciences that offer this course (HEG Coire for classes in German, and HEG Geneva for classes in French or bilingual classes in German and French).

- The branches taught are: "Working environment," "Information studies concepts and techniques," "Service and communication," "Management," "Project" (students have to complete a project on behalf on an institution), "Library science" "Archives administration," "Information management," "IT \& the Internet." Every student must write a bachelor's thesis on a topic in the field. Schools encourage information/documentation services to welcome students and submit projects, so that their bachelor's thesis can be built around a concrete project at an institution.

- Practical training: an eight-week internship in an information/documentation service during the course of studies.

- Evolution: since they practice research, HES universities anticipate changes in the professions and adapt the courses they offer in line with current developments in the field.

\section{Master}

- Admission requirements: bachelor's degree in documentary information or bachelor's degree in another field.

- Total duration: 2 years (the duration of studies is subject to the rules of the Bologna system $)^{10}$.

- Theoretical training: The goal is to give students a strategic vision of information management that allows them to plan, manage and conduct complex projects in their future careers. The branches taught are "Data and information science," "Academic research," "Management." Every student must write a master's thesis that

9 “Titre délivré", hesge.ch, https://www.hesge.ch/heg/formation-base/bachelorsscience/information-documentaire/titre-delivre, accessed on 20.01.2020.

10 "Titre délivré", hesge.ch, https://www.hesge.ch/heg/formation-base/bachelorsscience/information-documentaire/titre-delivre, accessed on 20.01.2020. 
provides an innovative perspective or new answers to a problem in the field.

\section{Continuing education}

As far as continuing education resulting in diplomas or certificates is concerned, several institutions offer various specialised Certificates of advanced studies (CAS) ${ }^{11}$ (for example, for school-based librarians) and Master of advanced studies degrees (MAS) ${ }^{12}$ for archival and cultural heritage management within the framework of an information/ documentation service.

Professional associations, on the other hand, offer short-term continuing education courses that encourage professionals active in the field to update their knowledge and discover new trends, in order to be able to handle new developments taking place in their professional environment. The various courses on offer illustrate the scope of the programmes ${ }^{13}$.

Bibliosuisse, the national organization of librarians, attaches great importance to professional training within its general strategy. In 2018, it has established a commission tasked with developing a continuing education program that is both attractive to professionals and convincing to employers. In order to respond as good as possible to the challenges that institutions face, the courses can take various forms. The Bibliosuisse program is intended to complement that of Biblioromandie, the organization of librarians in the French-speaking part of Switzerland. BiblioFR, finally, focuses its offer on the concrete needs of library professionals in the Canton of Fribourg.

\footnotetext{
11 "CAS bibliothèque en milieu scolaire", hepl.ch, https://candidat.hepl.ch/cms/accueil /formations-continues/formation-postgrade/offre-de-formations-postgrades/cas-certi ficate-advanced-studies/cas-bms-biblioth-milieu-scolaire.html\#presentation-formation, accessed on 20.01.2020.

12 "Objectifs", unibe.ch, https://www.archivwissenschaft.unibe.ch/cas mas_alis/obj ectifs/index_fra.html, accessed on 20.01.2020.

13 Bibliosuisse programme: https://bibliosuisse.ch/fr/Formation/Formation-continue/ Programme-de-formation-continue, accessed 25.01.2020.

Biblioromandie programme: https://bibliosuisse.ch/fr/Sections/Biblioromandie/Fo rmation-continue-Biblioromandie, accessed on 25.01.2020.

Programme de BiblioFR: https://www.bibliofr.ch/fran\%C3\%A7ais/formation/forma tion-continue/, accessed on 25.01.2020.
} 


\section{Vocational training at the Cantonal and University Library in Fribourg}

\section{A. A brief presentation of BCU Fribourg}

Founded in 1848, the Cantonal and University Library of Fribourg (BCU Fribourg) has a triple mission. It is a university library, but it is also tasked with preserving the Canton's cultural heritage and with serving the general public. It consists of a central library and 18 branch libraries at the University of Fribourg, who differ greatly in terms of their size, their resources, and their institutional context.

Approximately 100 people work at the BCU Central library (equivalent to 57 full-time posts) to which can be added about 40 professionals (or approximately 25 full-time posts) supported by the University. Its collections include 2.5 million documents, not counting photographic and special collections.

The BCU Fribourg is currently engaged in two major projects. It will face a four-year "transition period" in a few months, during which an architectural expansion and restructuring project will take place. At the same time, the library will migrate its system to Alma and Primo and become a part of the Swiss Library Service Platform (SLSP) - the first network of scientific and specialized libraries at the national level in the history of Switzerland ${ }^{14}$.

As an academic library, the BCU serves the needs of the University of Fribourg ${ }^{15}$. Founded in 1889, this university strives to be bilingual (French, German) and has 10,000 students from 110 countries spread over five different faculties, as well as 1,000 employees including teachers and administrative and technical staff.

\section{B. Welcoming people in vocational training}

The Canton encourages vocational training, and the BCU Fribourg has always had a particularly strong commitment to this process. Thus, one colleague devotes $30 \%$ of his or her work time to this task.

Among the various library-related types of apprenticeships, the BCU has decided to focus on Information and Documentation Agents (since

\footnotetext{
14 "SLSP", slsp.ch, https://slsp.ch, accessed on 22.01.2020.

15 https://www.unifr.ch/home/fr.html, accessed on 22.01.2020.
} 
1998, 35 apprentices have been trained) and Media specialists ${ }^{16}$ (two apprentices). A project to also host bookbinders (known as Print Media Operators ${ }^{17}$ ) and trade employees ${ }^{18}$ was postponed until after the opening of the new library, as the coming transition period will not provide the necessary conditions for receiving trainees. As a result, the BCU Fribourg has stopped hiring new apprentices since 2018.

Meanwhile, the library continues to receive interns preparing for their studies at a HEG (between 1998 and 2019, no less than 44 such people were trained). For these interns, the objective of spending time at the library is not to acquire generalist know-how, but to immerse themselves into a professional environment for a year, during which they learn (by doing) how to perform a number of tasks specific to their future professions.

\section{Recruitment}

The official Swiss portal for information on career, academic and career guidance lists the apprenticeship and internship openings available in Switzerland ${ }^{19}$; in addition, we publish postings for pre-HES trainees on a Swiss mailing list devoted to library and information science ${ }^{20}$.

Candidates are expected to submit a full application with a cover letter, a $\mathrm{CV}$, and study and work certificates. We then invite all the people whose application has passed a first eligibility test (on average 10-15) for a halfday of information and for an aptitude test. This test allows us to then select the 4-5 applicants who will be invited for individual job interviews.

\section{Special features of apprenticeships}

We set aside time for internships in other libraries and/or archives that can last from a few days to a few weeks. Through partnerships with

\footnotetext{
16 "Médiamaticien CFC" https://www.orientation.ch/dyn/show/1900?lang=fr\&idx $=30 \&$ id $=184$, accessed on 22.01.2020.

17 "Opérateur de médias imprimés CFC" https://www.orientation.ch/dyn/show/ 1900?lang $=$ fr\&idx $=30 \& i d=238$, accessed on 22.01.2020.

18 "Employé de commerce CFC" https://www.orientation.ch/dyn/show/1900?lang $=$ fr\&idx $=30 \& i d=99$, accessed on 22.01.2020.

19 "Rechercher une place d'apprentissage", https://www.orientation.ch/dyn/show /2930, accessed on 22.01.2020.

20 "Swiss list for information and documentation specialists", https://lists.switch.ch /sympa/info/swiss-lib, accessed on 22.01.2020.
} 
public libraries or school libraries, apprentices can even spend a whole year (the first or second of their apprenticeship) at another institution so that they can acquire a greater understanding of the specifics of the different types of libraries.

Apprentices work in all sectors of their institution according to a preestablished plan which takes into account both the training objectives in the various fields and, where possible, the schedule of their school education. Apprentices are supervised by established professionals, which ensures both the transmission of knowledge and the quality of the processes taught.

\section{E. Special features of pre-HES internships}

At the BCU Fribourg, the professional immersion internship includes work at two separate library departments: the circulation/access service (loan, interlibrary loan, information and reference) and one of the two cultural heritage departments (either Manuscripts, Incunabula and Archives, or Fribourg Collections and Cultural Activities).

\section{Conclusion: a few thoughts}

With the existence of various institutionalised training programmes, one might imagine that Switzerland features a high level of professionalization in the world of libraries. This assumption is partially true. As far as the canton of Fribourg is concerned, it holds true for school libraries from the upper secondary level onwards (senior high schools, gymnasiums), as well as for large cultural heritage, university or specialized libraries. The picture becomes more muddied, however, in public libraries in small municipalities, which employ people from different educational backgrounds that sometimes work on a quasivolunteer basis for years on end. In many cases, they can count on a rich professional experience and have proven skills in their respective fields. They undoubtedly contribute to the very existence of the libraries they work at, but they do not have systematic professional knowledge in the field of library and information services.

How then can we support these people who lack recognition because they have not completed the basic training required for practicing the trade? In addition to providing continuing education opportunities, we might envision a skills certification system for basic knowledge and 
know-how in the library professions. This certification system should assess theoretical and practical skills and take into account self-training or continuing education efforts. It would lead to official recognition by professional associations and employers. In addition, individuals should have the opportunity to improve their skills in a targeted manner, at affordable prices and within a reasonable amount of time.

It is to achieve this goal that the association Bibliosuisse has tasked its "Training" department with developing a new course for library workers. This course is intended for people who are working in a library or information service but have not undergone the appropriate basic training. Thus, the association could guarantee quality assurance and award a kind of certification accepted both by the cantonal authorities in charge of continuing education and by employers. A German-language version of such a programme already exists; the future will tell us whether it is good enough to provide this type of library employee with a sufficiently solid foundation of skills.

What, on the other hand, are the needs of professionals who already have both formal training and professional experience? They would obviously benefit from self-study and from taking continuing education courses, including workshops that give participants a lot of room for exchange. Discussions with colleagues from other institutions, or even internships at other library and information services, which might be similar to or very different from one's home institution, are all sources of inspiration and learning to become an actor in the evolution of one's own library. Let us not forget that we should not limit our learning to the technical skills of our chosen profession, but extend it to social, ethical, intercultural, and didactic competencies, as well as to skills in the field of communication and marketing.

Finally, we ought to participate in national and international congresses, which offer a unique opportunity to combine lectures from experts with structured debate between peers and informal exchanges during breaks and recreational activities. In this context, Switzerland, a small country surrounded by neighbours whose languages we speak, occupies a privileged geographical position that facilitates participation in the Bibliothekskongress in Germany, the congress of the Association of Librarians of France (ABF) or the Convegno delle Stelline in Italy. 


\section{References}

Admin.ch. "RS 412.10 Loi fédérale du 13 décembre 2002 sur la formation professionnelle (LFPr)". Le Conseil Fédéral Le Portail Du Gouvernement Suisse. Accessed January 18, 2021. www.admin.ch/opc/fr/classified-compilation/20001860/index. html.

Admin.ch. "RS 412.101 Ordonnance du 19 novembre 2003 sur la formation professionnelle (OFPr)". Le Conseil Fédéral Le Portail Du Gouvernement Suisse. Accessed January 18, 2021. http:/ / www.admin.ch/opc/fr/classified-compilation/20031709/ index.html.

Bibliofr.ch. "Formation Continue." Accessed January 18, 2021. https://www.bibliofr.ch/fran $\% \mathrm{C} 3 \%$ A 7 ais/formation/formationcontinue/.

Bibliosuisse. Accessed January 18, 2021. https:/ /bibliosuisse.ch/.

Bibliosuisse. "Programme De Formation Continue." Accessed January 18, 2021. https://bibliosuisse.ch/fr/Formation/Formation-continue /Programme-de-formation-continue.

Bibliossuisse. "Formation Continue Biblioromandie."Accessed January 18, 2021.

https://bibliosuisse.ch/fr/Sections/Biblioromandie/Formationcontinue-Biblioromandie.

FH Graubünden. “Information Und Dokumentation.” Accessed January 18, 2021. www.fhgr.ch/fhgr/fh-graubuenden-als-arbeitgeberin/lerne nde/information-und-dokumentation/.

Heg. October 2, 2020. "Information Documentaire."

www.hesge.ch/heg/formation-base/bachelors-science/informationdocumentaire.

Heg. February 27, 2014. “Titre Délivré.” www.hesge.ch/heg/formationbase/bachelors-science/information-documentaire/titre-delivre.

HEP Vaud. "CAS Bibliothécaire En Milieu Scolaire.” Accessed January 18, 2021. https://candidat.hepl.ch/cms/accueil/formations-conti nues/formation-postgrade/offre-de-formations-postgrades/cascertificate-advanced-studies/cas-bms-biblioth-milieu-scolaire.html \#presentation-formation.

Herbert, Staub. January 17, 2021. "Bibliothèque Information Suisse BIS.” Arbido, https://arbido.ch/fr/edition-article/2015-1/associati ons-i-d/biblioth $\%$ C3\%A8que-information-suisse-bis. 
Hls. "Apprentissage.” Accessed January 18, 2021. https://hls-dhsdss.ch/fr/articles/027827/2007-11-29/.

Orientation.ch. "Médiamaticien CFC / Médiamaticienne CFC." Accessed January 18, 2021.

www.orientation.ch/dyn/show/1900?lang $=$ fr\&idx $=30 \& i d=184$.

Orientation.ch. "Agent En Information Documentaire CFC." orientation.ch. Accessed January 18, 2021.

www.orientation.ch/dyn/show/1900?lang $=$ fr\&idx $=30 \& i d=17$.

Orientation.ch. "Employé de commerce CFC / Employée de commerce CFC." Accessed January 18, 2021.

www.orientation.ch/dyn/show/1900?lang=fr\&idx=30\&id=99.

Orientation.ch. "Le Portail Officiel Suisse D'information De L'orientation Professionnelle, Universitaire Et De Carrière." Homepage. Accessed January 18, 2021. http:/ /www.orientation.ch/. Orientation.ch. "Opérateur de médias imprimés CFC / Opératrice de médias imprimés CFC.” Accessed January 18, 2021. www.orientation.ch/dyn/show/1900?lang $=$ fr\&idx $=30 \& i d=238$.

Orientation.ch. "Rechercher une place d'apprentissage" Accessed January 18, 2021. https://www.orientation.ch/dyn/show/2930.

Slsp. "SLSP Swiss Library Service Plateform." Accessed January 18, 2021. https://slsp.ch/.

Swisslib. "Swiss list for information and documentation specialists" Accessed January 18, 2021. https://lists.switch.ch/sympa/info /swiss-lib.

Unibe.ch "Objectifs." Archivistique, bibliothéconomie, science de l'information. Accessed January 18, 2021. www.archivwissenschaft. unibe.ch/cas mas_alis/objectifs/index_fra.html.

Unifr. "Université De Fribourg." Accessed January 18, 2021. https://www.unifr.ch/home/fr.html. 